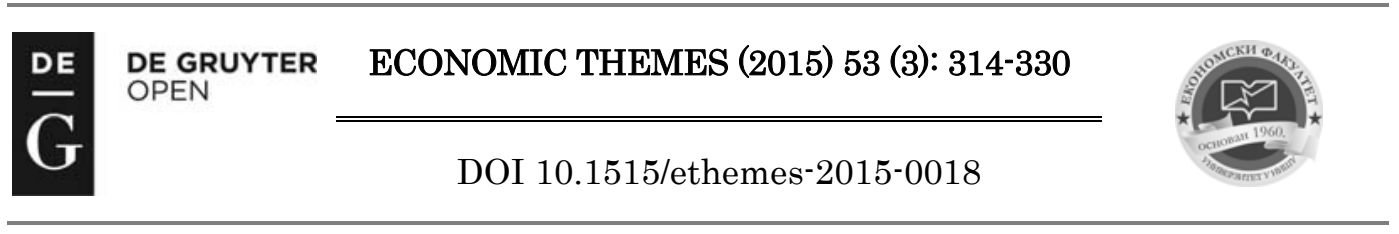

\title{
GEOGRAPHICAL DEVIATION AND HISTORICAL DEVELOPMENT
}

\author{
Miomir Jakšić
}

\author{
Univerzitet u Beogradu, Ekonomski fakultet, Srbija \\ $\triangle$ mjaksic@ekof.bg.ac.rs
}

UDC 338:9(5)

Review paper

Received:

10.12.2014

Accepted:

24.9.2015

\begin{abstract}
Different destinies of particular countries and nonexistence of warranted economic and social prosperity are explained by two paradigms: geographical and institutional one. Geographical paradigm insists upon the significance of physical geography, climate, ecology, that shape technology and individual behaviour. Institutional paradigm attributes the central role of institutions which promote investment in human, physical capital and technology. These two approaches have their roots in: 1 . Traditional society theory (Theory of Asiatic mode of production): differences in traditional societies of each country explain their different growth rates and level of economic development, and 2. World system theory: only countries that escaped colonial status have a chance to develop.
\end{abstract}

Key words: Asiatic mode of production, Institutions, Geographical deviation, Modern world system

\section{Introduction}

Theories of development drew attention to the modes of production, which makes it possible to discover, by interweaving and articulation of capitalistic and pre-capitalistic modes of production, the driving forces, mechanisms and outcomes of the disappearance of modes of production and also enables simultaneous explanation of both internal and external causes of underdevelopment, relying on the theory of the Capitalistic world economy (Moulder, Keyder, 1982).

The general model of development initiated from inside or outside, shows that development, as a succession of modes of production, took place in different ways, within the framework of the multilinear course of world history, and the driving forces, mechanisms and outcomes are different. In Western Europe those driving forces stemmed from the sphere of production (internal) enabled the transition from commercial to industrial capital, while in the East, 
those forces came from the sphere of trade (external), or were imposed by the colonizers, so there was no crossing from commercial to industrial capital. Development of the Orient is linked to these theories - the traditional society and the world economy theories.

\section{Asiatic mode of production}

Based on all elements, the East separates from the West, so the theory of the Asiatic mode of production is in essence interdisciplinary:

- in the field of economic theory, it deals not only with one specific, geographically limited space, but, in the broadest sense, with the role of factors of production and technology, relations to nature, stagnation, attitude towards the social superstructure and the domination of the noneconomic instances.

- in the scope of political theory, this concept and its history are important because, in comparison to the classical Western European model, it differently explains the formation of classes, the state, the circumstances in which there is no private property and where the state has a primarily functional role, rather than instrumental one - as an instrument of the rule of one class.

- in the philosophical aspect, this concept explains the role of religious factors in explaining the stagnation that occurred after the initial take-off.

Europe has had a varying attitude toward Asia: from the initial enthusiasm for the political and economic reality of the East (sinophilia), to the outbreak of colonialism, causing the condemnation and emphasis on stagnation, despotism and backwardness (sinophobia).

The theory of the Asiatic mode of production makes it possible to understand processes of socioeconomic development different from the WestEuropean ones, which were, based on the Eurocentrism, presented as a general model of the human development.

In the example of Asia, the limited applicability of the categories and laws of the West Europe's development becomes visible. This challenges the thesis on the development path once expressed through the five-stage scheme (primal community - slavery - feudalism - capitalism - socialism).

The issue of the oriental societies and the Asiatic mode of production again gains the attention of scientists. From the XVII century literature devoted to this problem has been growing. Initially, traders, travellers, diplomats, missionaries who travelled to Asia and Europe, brought the first and hitherto only news about the life and social organization of the Asian nations. The issues of the East were later on discussed by Bernier, Smith, Hume, James Mill, John Stuart Mill, Montesquieu, Voltaire, Quesnay, Hegel, Herzen, Plekhanov, Marx, Engels, Lenin, and others. 
In the twentieth century discussion on the Asiatic mode of production was restored on several occasions. In the 1920s and 1930s, there were discussions in the USSR (Leningrad discussion), China and Japan. After the Second World War, many countries of the world like England, France, Italy, Hungary, Germany, the USSR, Japan, China, the United States write about the Asiatic mode of production.

The discussion on the Asiatic mode of production was and still is the centre of discussion on the dynamism/stagnation, revolutionarity/evolutionism of society in general. It is a paradigmatic example to demonstrate the advantages of one model or the other as well as the coincidences (a) dynamism and revolutionarity in the West that breaks all connections with pre-capitalism and (b) the coincidence of stagnation and evolutionism in the East. The example of the Asiatic mode of production is used in the theoretically and practically for verifying (a) one development model and (b) its foundation in the West.

The issue of the Asiatic mode of production was mainly approached from the Eurocentric positions - humiliating the cultural heritage of the peoples in the East, overemphasizing the negative elements of oriental despotism. In addition, the economic base was being simplified and narrowed down as the necessity for public works, done by the state, regulation of the water supply, so in pejorative sense these societies were called the Hidraulic societies, as if there were no other features of the great Eastern civilisations, but the irrigation works.

Many scientific and technical achievements that emerged within the Asiatic mode of production, which even though it was in its own way developing its production over time, as well as other modes of production became its obstruction. In 868. in China first book was printed using the technique of moving letters, and 600 years later the first such book was printed in Europe (Gutenberg, 1446, Mainz); paper money existed in China in XIII century; the Europeans took the secrets of producing silk, gunpowder, the compass from the Chinese. By that time, China had achieved significant results in the development of agriculture, trade and overseas trade. All this could not occur without a developed economic base - the Asiatic mode of production.

The alleged "blame" of the Asiatic mode of production for the slow development in the areas dominated by the economic model today is difficult to assess, given the fact that the imperialist expansion destroyed entirely destroyed it and pouring the accumulation into the colonial metropolis. The autochthonous development and character of the Asiatic mode of production was in this way shattered, and thus the debates on the guilt of certain models of economy amount to scholastic discussions, often marked with Eurocentrism. ${ }^{1}$

\footnotetext{
${ }^{1}$ About the achievements of the Chinese civilization see Étiemble, Connaissez-vous la Chine? (Do you know China?), Gallimard 1964, and C. Hucker, (1975) China's Imperial Past, Duckworth.
} 
The Western view of the Orient as a history of despotism and bloody confrontations is still dominant today. After all, Marx's understanding of Asia is an example of the Western vision of the East, combining facts and fantasy (O'Leary 1989; Jakšić 1991).

European thought is optimistic, it is a variant of the Renaissance and nineteenth-century theories of progress: social order free from violence, oppression, domination, exploitation; it is not only possible, but inevitable, because they are not inherent attributes of human society. The history of human society is the history of class struggles, it is the history of the development of production forces. Opposite to those ideas there exists the Asiatic mode of production, as a model of social order in which domination and oppression prevail, they are stable and safe, not arising from a pre-existing unstable system of class exploitation. Classes, the key dramatic characters, are the state bureaucrats, soldiers, officials, and they did not exist prior to the system. They were not created by the system, they created it. Thus, domination is not a servant of economic exploitation, but its independent primum mobile. In the Asiatic mode of production, stagnation and pessimism suppress the infinite optimism, and this can only be explained by the Eurocentrism, whose theoretical and practical interest is moving within the area between the Mediterranean and the North Atlantic.

The debate on the Asiatic mode of production raised a number of fundamental theoretical questions about relationships between:

- evolution and revolution;

- stagnation and dynamics;

- functionalism and instrumentalism.

Western interpretation of the East highlights the elements of long-term evolution resulting in stagnation that imposes comprehensive functionalism on the state, which, on its own causes decline in economic and social returns.

Model of the Asiatic mode of production, in the Western view, has the following characteristics:

1) long-term evolution;

2) stagnation;

3) functionalism;

4) decreasing economic and social returns.

Two development theories explain the process of socio-economic development of the East: (1) internalist - seeking the causes of development / underdevelopment in the internal factors; (2) externalist - explaining the process of developing at the level of influence of external factors - colonialism.

At the centre of interest are the following questions:

- Does the East have the history of the development of its own, or is it only the history of colonial invaders? 
- To what extent in the countries of the East act general or specific rules of development?

- Is capitalism the consequence of the indigenous forces or imposed from outside?

- Does colonialism encourage the development of creates underdevelopment?

- What is the impact of religion and ethics on social and economic development of the countries of the East?

F. Moulder gives typical views of one and the other theory:

a) theory of traditional society: the differences of traditional societies caused the same influence to give different results;

b) theory of world economy: Japan has developed because it is the only country that had escaped the colonial status.

The example of Japan is quite significant for both theories and it is an exception that proves the rule:

- for the theory of traditional society, Japan is a feudal society, unlike other Asian societies;

- for the theory of world economy, Japan joined the world economy later and by other means than the other countries in the East, and this is why it developed.

From the standpoint of the theory of world economy, Japan evaded bad faith for two reasons:

a) colonial conquests were primarily aimed at china, India, and not Japan;

b) when Japan came into the focus of interest, there were violent clashes between the colonial cities, which enabled Japan to join the world trade by economic and political means, rather than military submission. Hence the conclusion that China and Japan were feudal societies and similar as such, and the fact that Japan developed and China remained underdeveloped can only be explained by the fact that Japan avoided the status of a colony.

F. Moulder emphasizes that this interpretation can be challenged on several grounds:

China was not a colony, but a semi-colony, and Japan was in this position as well, so the external influences were the same, not different; societies in China and Japan differed (China was not feudalism of the West - European type, but a bureaucratic feudalism) and this was crucial for further development.

The theory of traditional society gives priority to the internal factors and external factors are subordinate to them, and in the case of China and Japan it points out that China responded to violent impacts significantly less, whereas Japan reacted much more completely, along with the fact that those impulses were peaceful (there was no smuggling, opium, wars, conquering territories). 
This stunning paradox can only be explained by the differences in traditional societies, so in this context the different development conditions are emphasized. Thus, Moulder points to three types of reasons: the necessary (they are latent and do not incite development); initial (political and economic institutions); sufficient (activate the potentials of the two stated series of conditions). If there are the necessary and initial conditions, then the external influences are not required as sufficient. Within the theory of traditional society, two groups of theories are differentiated:

1) development factor theory, and

2) ideal types theory.

The factor theory stresses the factors too particularistic and distinctive to be used as a measuring unit of development / underdevelopment. For Japan, these factors could be the insular position, militarism, pragmatism, loyalty, religion, nationalism, progress of the traditional economy. In addition to the shortcomings of its general approach, the theory suggests that same factors are drivers of development in some countries and cause underdevelopment in other countries (example of vast territory bringing development to the USA and causing underdevelopment in China).

The theory of traditional society has the following shortcomings:

a) there is no unambiguous link between the cities' autonomy - the rise of commerce, industrialization (the English cities were more dependent on the feudal rule compared to Germany, and yet England developed);

b) the commercial bourgeoisie proved incapable of generating development without government incentives;

c) there is no analogy between the bourgeois control over the state and the government incentives of development, because the state encouraged development in the feudal times as well;

d) Japan being a feudal society (in the spirit of traditional society theory) cannot explain why the transition to capitalism in Western Europe was induced by internal factors, and in Japan it happened when external factors got involved.

The key questions are the following: Are Japan and China different from one another? Do Japan's and China's relations to the outside world differ?

Analysing the first question (the thesis of the traditional society theory), F. Moulder concludes that the traditional society theory overstressed the differences between the Qing China and Tokugawa Japan, on the one hand, and the similarities between Tokugawa Japan and the then Western Europe, on the other. Both countries were agrarian, producing the same products, and the share of the population working in agriculture, as well as the share of agriculture in the national income, was similar. The textile industry on the craftsmanship level was significant in both countries. The changes that started earlier in China and 
lasted shorter in Japan, were also similar (increased productivity in agriculture, trade growth). The most important indicator of change is the commercialisation, which goes from extensive (expansion) to intensive (deepening). The extensive is linked to trade, and the intensive increasingly for production, and in either of the countries the shift from extensive to intensive commercialisation did not happen, which is confirmed by the similar share of traded products in the total production of each country (about 30 percent).

F. Moulder points out that the connections with China are developed, the share of foreign investments increased significantly, whereas this was not the case with Japan; apart from the economic significance, the great significance for China was political and military penetration that resulted in eliminating the weak stated, while in japan that weak feudal state was turned into a bureaucratic and national state, which was important for the process of government incentives of industrialization. A.K. Bagchi distinguishes three periods of exploitation: 17571813 (mercantilist exploitation; the monopoly of the English East India Company in the trade with India was abolished in 1813, with China in 1834, and in 1858 the governance of India was definitively subordinated to the British Parliament); in the period 1858-1914., the free trade flourished, and the period 1914-1947 marks the end of colonialism and the establishment of neo-colonialism.

\section{On "Geographical Deviation"}

The interpretation of the role of natural property reaches climaxes with the industrial capitalism and the question to what extent the environment crucially determines the pace of economic growth and development and whether political institutions can accelerate or retard this growth.

The greatest suppression of the role of geographical factors is related to the five-member single-line scheme of the social and economic development, which was institutionalized under Stalin. M. Sawer (1977) wrote: "Marx's overall analysis of the development of East and West was entirely based on the use of geographical factors as the source of these differences" ${ }^{2}$

In addition to soil fertility, Marx emphasized the closeness of territories and vastness of spaces: closeness conditioned the exchange of goods and vast space influenced the emergence of despot systems (Sawer, 1977, p. 167; Marks, 1977, p.160). The difference that separates M. Sawer from earlier thinkers is that the influence of environment weakens with the development of production forces. In the beginning of the production took place under the direct influence of the environment (Marks, 1971, p. 185).

\footnotetext{
${ }^{2}$ Sawer, M. (1977) Marxism and the question of the asiatic mode of production, Martinus Nijhoff, Hag, p. 167; Marksizam i pitanje azijskog načina proizvodnje, prevedeno, Veselin Masleša, Sarajevo, 1985. In further text cited in the original edition.
} 
This influence fades later on: "Hence the great civilizing influence of capital; its production of a stage of society in comparison to which all earlier ones appear as mere local developments of humanity and as nature-idolatry. For the first time, nature becomes purely an object for humankind, purely a matter of utility; ceases to be recognized as a power for itself; and the theoretical discovery of its autonomous laws appears merely as a ruse so as to subjugate it under human needs, whether as an object of consumption or as a means of production". This, M. Sawer points out, confirms Marx's general approach to history as the "subjugation of nature under human needs" (Marks, Engels, 1948, p. 26).

Other Marxists were less convinced of this almost insignificant influence of nature, especially G. V. Plekhanov, whose views were long described as "geographical deviation" (Jakšić). Soviet science, for which this issue is rather significant considering the dependence of the natural environment - production powers - social development, interprets Plekhanov's theory like this: natural environment has an accelerating or halting effect and with development this effect weakens. Plekhanov's attitudes oscillated between the thesis of accelerating or halting effect and thesis of the determining role and hence he failed to resolve these two completely different approaches.

The first attitude could be supported by Plekhanov's view: "Modern dialectical materialism shows that the geographical environment provides men with a greater or lesser possibility of developing their productive forces, and thereby pushes them, more or less energetically, along the path of historical progress." And elsewhere he writes: "The properties of the geographical environment determine the development of the productive forces, which in turn determines the development of the economic forces, and therefore of all other social relations" (Plehanov, 1964, p. 165).

The main conclusion about the role of the environment made by the most prominent actors in the discussion on the Asiatic mode of production is that Plekhanov strengthened the elements of geographical determinism that Marx inherited from Hegel and Montesquieu and that he was himself under the influence of Mechnikov and Ratzel. Plekhanov wrote: "The whole question of the development of the economy to that of the causes determining the development of the productive forces at the disposal of society. In this, its final form, it is solved first and foremost by the reference to the nature of the geographic environment."

This different influence of the environment Plekhanov illustrates with examples of the European and Oriental developments as bilinear models: "If these two types differed considerably from each other, their chief distinctive features were evolved under the influence of the geographic environment, which in one case prescribed one kind of aggregate production relations to a society that had achieved a certain degree of growth in the productive forces, and in the other case, another kind, greatly differing from the first." 
Plekhanov is in this sense more of a determinist than Marx, which is obvious from his critics of the Mechnikov's book, Mechnikov being on his part under the influence of the "possibilism" of Élisée Reclus: geographical factors of the River Nile leave an open choice between despotism and equality of all. Mechnikov emphasized the role of fertile river valleys that conditioned the centralized organization of production and growth of work productivity. The most suitable environment for development in this regard was the Mediterranean, which suited Hegel and his views on the historical development and the role of "fertile Oriental river valleys".

A Russian historian Solovyov wrote: For the Western Europe and its peoples the nature is a mother; to the East and the peoples destined to create history, she has been a stepmother". In the conflict of those who emphasize the specific character of the Russian history and those who point to the universality of the law, Plekhanov's concept emerges. E. Hobsbaum formulated it like this: if there are general laws of development, then the people of the East that are underdeveloped are exception, and if there are no such laws, then the Western Europe is an exception because it did develop.

Analysing Russia, K. Marx used an adapted version of the Asiatic mode of production and Asian despotism, and his interest in Russia stemmed from the conviction that the destruction of Russian aristocracy will be the key to success of the revolution in the West. His general views were based on the belief that the development of socialism required the "material foundations of Western society". M. Sawer concludes: "Marx and Engels followed the great traditions of the West European political theory and described the state in Russia as Oriental or semi-Oriental despotism".

Until 1858., as pointed out by M. Rubel, they viewed Russia as an immobile semi-Asiatic colossus and a bulwark of European reaction. This is particularly emphasized in the History of Secret Diplomacy of the XVIII century, where K. Marx views the history of Russia as feats of great people - peasants who with the help of their cunning and crafts turn Russia into a great empire, which is a complete different explanation from the one that applies to Western Europe (Sawer, 1977, p. 222).

Even though he attributed a significant role to the political factors in the East, Marx distanced himself from the historical school, according to which the Russian state is "a state completing tasks", and as pointed out by B. N. Chicherin who claimed that "obshchina and peace" are products of the activities of small states and rather than the consequence of the primal community as suggested by Marx. Still, Russia was different from the East because the vicinity of the West pressed autocracy to adopt the modernization programmes in order to keep the military supremacy over with the Western neighbours which was illustrated by Marx in History of Secret Diplomacy with the example of Peter the Great, who invited western experts to introduce western 
achievements into Russia and at the same time he also reinforced the Asian (Moscow system).

Marx's model excluded the possibility of economic modernization and industrialization. Despite differences in the interpretation of nature "peace" and "obshchina", Marx's view of Russian history was close to interpretations of a state that completes tasks, offered by Solovyov and the most prominent representative of which was V. O. Klyuchevsky. This school is a combination of elements of Western historiography, geographical determinism of Hegel and Buckle, economic determinism and neo-Hegelian theory of the state as a creative entity. land:

Solovyov writes about the three elements that had a particular impact on the

- The nature of the land that people inhabited;

- Nature of the tribe;

- Course of external events.

These elements are taken over by Plekhanov, who sees the essence of the Asian despotism in the need to defend from the nomads (Tatars) rather than the need to make water management works like in the East. Solovyov emphasizes that the mountain ranges in the Western Europe and the maritime routes caused the diversity in development and separated the countries, whereas in the East the plain is everywhere even so it did not encourage specialization nor was it possible for original centres of certain crafts and trade to develop.

Plekhanov points out that there were not mountains of construction material for building castles, so the nobles lived together with the people in the communities (companies). Klyuchevsky in his lecture "History of Estates in Russia" in 1886 at Moscow University noted that the most important element is than the state's primacy lies in the economic and social life, unlike Europe where the primacy is given to economics. This was criticized by Plekhanov, saying that there were "mixed processes" in Russia.

By Klyuchevsky, this is conditioned by the nature of East-European planes, the exposure to nomad attacks and the government structure of the state that played a very important role in contrast to Western Europe. Besides defence missions, the state created a military-feudal class and gave it land for keeping and in return it served the state. Moscow classes differed from the Western ones because "they were divided into levels that were in the official Moscow jargon called ranks"; or "the position of an individual or a class in the state was actually determined by their duties to the state" (Sawer, 1977, p. 228).

Thus the state prevented leaving out any part of land from the state treasury and not charging for it. Apart from Solvyov and Klyuchevsky, the most systematic theory of the service state was given by P. Milyukov: external demands on the state on a certain level of development conflicted with the economic and social development and as the commodity economy still was not 
developed, the state was forced to turn to the service class; thus was formed the "service class" system rather than independent feudal classes.

Russian Marxists completely neglected Marx's model of the Asiatic mode of production and great historical theories of historians like Pokrovsky, Solovyov and Milyukov. Due to this, another approach developed "cladding Russian history in European robes" following the form of the five-member scheme and emphasizing that there had not been a distinctive Asian development but a West-European one. The founder of this orthodox interpretation is Pavlov-Sil'vanskii, who proved the similarity between the Russian and West-European feudalism and pointed out that this system had developed or the same reasons - the conflict between the landowners and peasants rather than the dominance of non-economic factors - the state from above; here as well the development is incited from below through economic class struggles. His thesis was continued by Pokrovsky, who searched for solution for weak development of Russian feudalism compared to European feudalism in changing its periodization so that there was no slavery and the rise of the bourgeoisie was already tied to the XVI century, so the appearance of bureaucratic structures is linked with the original accumulation.

There are two versions: the distinctive one of Solovyov, Klyuchevsky, Milyukov and the orthodox one by Pokrovsky and Pavlov-Sil'vanskii. The most significant Marxist that will consistently apply the concept of multiline development on Russian history is G. V. Plekhanov, whose theory is founded on (a) Marx's theory of the Asiatic mode of production and (b) the Russian historians' theory of service state. This is linked to the political conflict between the People's and Social-democrat parties; the people's party argues that Russia can use the experiences from the Western development and by avoiding capitalism, it can switch directly to socialism while the Social-democrats based their concepts on the West-European model of development. Plekhanov rejected the theory of completely distinctive Russian development - the People's theory, as ungrounded, but he also rejected the one emphasizing the Western nature and pointed out that Russia was Asian in different periods (Ivan the Terrible), or more European (Peter the Great), hence the "mixed processes" - interweaving the European and Asian economy and politics. There is "relative distinctiveness" of Russian history and the world history is divided into two great courses: European and Asian, while Russia is separated from them and oscillating between them. He rejects Solovyov's elements (geographical environment, nature of the tribes and external events) and modifies them: the tribal conflicts did not play a more significant role than the economic ones and the formation of classes is determined both economically and politically. He writes: "The course of events here as elsewhere has always been subjected to natural conditions. The relative distinctiveness of the Russian historical process is actually explained by the relative specificity of the geographical environment in which Russian people had to live and work". However, he criticizes Solovyov, who stresses the direct 
influence of natural environment: according to Plekhanov, this influence is always only indirect through the development of productive forces.

Turning to the factor of social relations, he suggests that society constantly reproduces similar to biology, and that instead of creating different production organisms, it constantly produces the same because the production conditions for a new unit are the same as for the old one. Besides the reproduction of the same communities, the abundance of fertile land disabled the development of a complex social division of labour: lack of diversity prevented the horizontal division of labour and land disposal prevented the vertical division.

The vastness of the Russian plane disabled the strengthening of dissatisfied social layers: in the West, dissatisfied peasants fled to the cities where they could gain economic and political freedom, whereas here, there were no cities, so they fled to the steppes where economic relations were underdeveloped compared to the central state regions. Peasant uprisings did not result in any changes, they only reproduced the "Mandate of Heaven", just like in China. Thus the spaciousness and monotony of the Ease-European plane halted the development of Russian feudalism. Still, in the Kiev period, Russia traded with the West, but later on it closed especially because of the openness of the plane to the South-East and exposure to nomad attacks which became increasingly dangerous during the Kiev period (but this again is not a theory of "conquest", but naturally conditioned development). Geographical environment in the North was even more unfavourable for the Western development than in the one in the South, so the state settled its expenses with agricultural products; it took from farmers a bigger surplus that before and in order to do that it increased its power.

Thus, in the Kiev Russia a system was developed that, unlike Moscow, was closer to the Asian, only here the focus is on the defence from the nomads instead of irrigation. Nomad people were stronger than the settled farmers, so they united into large groups and apart from the peasant mass they could also allocate a great number of people for the army.

Although under Tatar attacks the South centre was moved from Kiev towards Moscow, Plekhanov denies there was a tatarization of Russia. The changes were a response to the Tatar intrusions not the adoption of their social system. Thus, all the land, instead like in the Kiev period, became property of the state and the ruling regime became stronger, which is confirmed by the descriptions of Fletcher and Herberstein; Fletcher wrote: "the rule there is purely tyrannical; all its actions aim to the sole benefit and gain of the Emperor".

Herbstein wrote: "They are all slaves or servants to the Prince". Ivan the Terrible ended the process of transforming Russia into a "Eastern type monarchy", whereas Peter the Great simultaneously changed and reinforced the Asian system: nobility had greater power over land, it was to some degree freed from servitude and it became more like the nobility in the West, but servitude of the peasants became even harder: "Therefore, the social position of the "noble" class was 
shifting to to one direction - towards the West - while at the same time the social position of the "lower people" was still moving in the completely opposite direction - towards the East. Plekhanov was always sensitive to the Asian past of Russia: he opposed the description of Russia after 1861 as a "European China", but he also fought against the restoration of "our political-economic Chinese"

He writes: "The essence of Chinese social revolutions lies in the confiscation of land from the "holders" and its return to the State-Leviathan and then the old history begins again, there are new "holders", new revolutions and the old "Chinese" are restored. We do not need Chinese. That is why we support peasant movements only as much as they destroy the old order, but not when they are trying to restore the system that makes the old one seem progressive and advanced".

M. Sawer concludes: "The significance of Plekhanov's contribution to historical materialism is not in the popularization of the thesis of accelerating / retarding consequences, but in a different approach to the geographical factor that dominates his works: the role of the geographical environment has always been extremely important for determining the nature of social relations" (Sawer, 1977, p. $185)$.

K. Wittfogel in a series of articles titled "Geopolitics, Geological Materialism and Marxism" criticized the dematerialization of history by "social conditions" of production: such conditions existed, for example, in France, but still the bourgeois revolution did not yield capitalism. Wittfogel raises the question: Why? Because of the natural environment and the scarcity of iron and coal and their unfavourable location. This is why Wittfogel insisted on separating and differentiating naturally and socially determined productive forces: natural are water and mineral wealth, and social are technology and organization.

J. V. Stalin in his work Dialectical and Historical Materialism "cut off" these discussions with his assessment: "Geographical environment is unquestionably one of the constant and indispensable conditions of development of society and, of course, influences the development of society, accelerates or retards its development. But its influence is not the determining influence, inasmuch as the changes and development of society proceed at an incomparably faster rate than the changes and development of geographical environment".

Natural environment, hence, does not have a determining influence, it can just retard or accelerate development. Later "destalinization" led to resistance to such views and return to Plekhanov. At that time, certain authors even claimed that Stalin's "geographical nihilism" was more harmful than determinism. Rejecting the minimization of the role of natural environment resulted in the view that natural environment constantly changes and that considering the interrelations between nature, humans and society, it is in a feedback loop.

\section{Economic Development and Role of Geography and Institutions}


Geographical factors have a significant role in determining the location and level of interactions of those ancient agricultural civilisations. L. Putterman writes about this subject in particular, and we present his work in further text (Putterman, 2014).

What and how big is the role of historical factors in explaining great differences on the level economic development between different countries and regions in the world today? The level of economic development and the growth rate since the end of the European colonial era has greatly depended on the average level of technology and political position of the area where the ancestors of today's inhabitants lived long before or immediately before the colonial era. The interplay between geography and human capital, broadly viewed as culture, norms and institutional capacities have a central role in explaining those differences (Putterman, 2014).

In the early 2000, D. Acemoğlu proposed an approach based on emphasizing formal institutions and property rights as the alternatives for the geographical approach (Acemoglu et al. 2001; Acemoglu et al. 2002). ${ }^{3}$

Acemoğlu interprets different fates of individual countries and a lack of guaranteed and secured economic prosperity by two paradigms: geographical and institutional (Acemoglu, 2003). Geographical suggests that geography, climate and ecology shape the technology and individual behaviour. Institutional gives the central role to the institutions that encourage investments in the human and physical capital, technologies and incite overall development.

Good institutions possess three characteristics:

First, they establish and protect property rights in society;

Second, they restrain all possible elites that seek to expropriate someone's income or assets; and

Third, to the greatest possible extent, they provide equal opportunities for the broadest population in the fields of employment, social security and human rights.

Where there are no such good institutions, proves Acemoğlu, there is no economic and social prosperity. There is a correlation between geography and prosperity, but the correlation is not causality.

Is order to assess the relative significance of geography and institutions Acemoğlu examines the external causes of changes of institutions, except the geographical ones. Colonization is for him and example of such possible experiment: in the colonies it introduced and modified many institutions of the native people, without changing the geography. If geography were crucial, rich countries would have remained rich after the colonization and arrival of the

\footnotetext{
${ }^{3}$ Also see the Serbian translationof his book Ekonomsko poreklo diktature i demokratije, Zavod za udžbenike, Beograd, 2013.
} 
Europeans, and they would still be rich today. On the other hand, if the institutions have the key role, the introduction and development of new European - institutions would be crucial, and those good institutions would incite development, unlike those areas where the colonization brought just mere robbery without any development of institutions.

L. Putterman seeks answers to these questions in the geographical factors and the spirit of the great discussion on the Asiatic mode of production and the subsequent discussion on Geographical deviation in the time of J.V. Stalin in the USSR. Some non-European areas were relatively developed at the beginning of the colonial era - the Aztec and Inka empires, but they were lagging by the end of that era, whereas some others that used to be undeveloped (USA, Canada, Australia, New Zealand) progressed in time. Acemoğlu termed this "shift of wealth". He showed that in the in general cases, colonized countries that were developed in 1500 , measured by the share of urban population and population density, were less developed in 1995. Acemoğlu et al. admits that the conditions in colonized countries - deadly environment for European people or the population density - can help to explain why some developed and the others did not. The key factor, according to them, is whether the colonizers who created in colonies extractive institutions that favoured violent exploitation of labour and natural resources, or inclusive institutions, primarily property rights that encouraged investments in knowledge, skills and physical capital.

Why the Western and Northern Europe, and not previously developed Southern Europe or the heart of Eurasia, including China, were the ones that colonized other continents, and thus the first to be industrialized, is a question that economic historians and growth theorists have been discussing for a long time. The story about the Chinese naval fleet led by Admiral Zheng He, that by far surpasses the ventures of Columbus, da Gama and Magellan in its size and number and size of the ships, that sailed into the ports around the Indian Ocean to affirm the power of China, gained popularity because its significance for this discussion.

Works of P. Diamond and D. Landes pointed to the differences in the nature of the rule over the huge areas of China by a powerful ruler and competition between many small stated in Europe that increased the chances for different strategies to be supported by different groups. They suggest that the differences in the nature of political unifications resulted from different geographies: Chinese fertile river valleys and plateaus in their vicinity conditioned the rise of a continentally oriented civilisation in which there were not a lot of peninsulas and islands, while Europe had plenty of large peninsulas (Iberian, Apennine, Scandinavia) and islands (Britain, Ireland, Sicily) (Diamond, 1997, according to: Putterman, 2014).

Morris attributes the European, not Chinese, "discovery" of America to smaller distance and more favourable sea currents and winds that suited Europe compared to Chinese maritime routes across the Pacific (Morris, 2010, 
according to: Putterman, 2014). Acemoğlu explains this rise by favourable political institutions, not geography.

\section{Conclusion}

The colonization experience is in this sense instructive, because the Europeans used different strategies: somewhere they created "bad institutions" - slave trade in the Caribbean, forced labour in Central America - that were instruments of robbery, and their aim was not to establish or protect property rights, restrict the elite and expand human and social welfare. On the other hand, in some colonies there were colonial settlements that were replicas of those in the metropolises settlements in Australia, New Zealand, Canada and the USA - where there were empty territories, with scarce resources and unfavourable climate. They rested on "good institutions" and incited development. In the first case, favourable geography and bad institutions did not initiate development, and in the second the unfavourable geography and good institutions did, which indicates the predominant role of institutions for social development.

In the colonies where the Europeans did not care for food institutions that would establish and protect property rights and limit the autocracy of the elite, development was obstructed and those societies are in an unfavourable position compared to the one half a millennium ago. Acemoğlu's arguments are an echo of the great discussion on the Asiatic mode of production and Geographical determinism, the central actors of which were Lenin and Plekhanov: Plekhanov linked the dangers of despotism, underdevelopment and Asian ways to unfavourable climate conditions and lack of institutions, whereas Lenin sought the drivers of socialist progress precisely in this.

\section{References}

"Azijski način proizvodnje" (1982) Marksizam u svetu, Beograd 2.

Acemoglu, D. (2003) "Institutions and economic development", Finance and Development, br. 2.

Acemoglu, D., Johnson, S. i Robinson, J. (2001) "The colonial origins of comparative development: an empirical investigation", American Economic Review, 91(5): 1369-401.

Acemoglu, D., Johnson, S. i Robinson, J. (2002) "Reversal of fortune: geography and institutions in the making of the modern world income distribution", Quarterly Journal of Economics, 117(4): 1231-94.

Ačemoglu, D., Robinson, Dž. (2013) Ekonomsko poreklo diktature i demokratije, Zavod za udžbenike, Beograd.

Etiambl, R.(1968) Poznajemo li Kinu, Vuk Karadžić.

Hucker, C. (1975) China's Imperial Past, Duckworth.

Jakšić, M. (1991) Azijski način proizvodnje, Naučna knjiga, Beograd.

Jakšić, M., "Koncepcije Lenjina i Plehanova o azijskom načinu proizvodnje", Ekonomski anali, br.63-64. 
Marks, K. (1971) Prilog kritici političke ekonomije, BIGZ, Beograd.

Marks, K., F. Engels (1948) Komunistički manifest, Kultura.

Moulder, F., Keyder, C. (1982) Marksizam u svetu, Beograd, br. 2.

O'Leary, B. (1989) The Asiatic Mode of Production, Blackwell, Oxford.

Putterman, L. (2014) "History and comparative development." The New Palgrave Dictionary of Economics. Online Edition. Eds. Steven N. Durlauf i Lawrence E. Blume. Palgrave Macmillan. <http://www.dictionaryofeconomics.com/ article?id=pde2014_G000223 $>$ doi:10.1057/9780230226203.3921. [22 May 2014]

Sejver, M. (1985) Marksizam i pitanje azijskog načina proizvodnje, Sarajevo: Veselin Masleša.

\section{GEOGRAFSKA DEVIJACIJA I ISTORIJSKI RAZVOJ}

Apstrakt: Različite sudbine pojedinih zemalja i nepostojanje garantovanog i osiguranog ekonomskog i društvenog prosperiteta tumače se dvema paradigmama: geografskom i institucionalnom. Geografska smatra da geografija, klima, ekologija uobličavaju tehnologiju i ponašanje pojedinaca. Institucionalna, centralnu ulogu pridaje institucijama koje ohrabruju investicije u ljudski, fizički kapital, tehnologije i podstiču sveukupni razvoj. Ova dva pristupa imaju svoju preteče u 1. teoriji tradicionalnog društva (azijskog načina proizvodnje): razlike tradicionalnih društava uslovile su da isti uticaj uzrokuje različite stope rasta i novoe razvoja, i 2 . teoriji svetske privrede: samo zemlje koje izbegnu status kolonije imaju šanse da se razvijaju.

Ključne reči: azijski način proizvodnje, institucije, geografska devijacija, savremeni svetski sistem 